\title{
Berlin 1996
}

\author{
By Jiří Voráč
}

Fall 1996 Issue of KINEMA

\section{THE CRISIS OF STORIES, THE PATHOLOGY OF LONELINESS, THE POETICS OF CHAOS}

THIS year saw a course change in the international film festival in Berlin. In the past, the Berlinale had cast itself mainly as an overview of artistically demanding works by significant directors, paying special attention to smaller, less traditional film industries (Central and Eastern Europe in the 1980s, Asia in the 1990s). Time was also devoted to independent film-makers and minority genres (homosexual film, for example). This year, a commercial orientation clearly predominated, and the festival's official image was formed by larger, star-studded Hollywood productions whose glitter was emphasised by personal appearances of the visiting celebrities.

\section{A crisis of themes, personalities}

This year's festival manifested a lack of new creative personalities and artistic impulses, such as the "independent" generation (Jarmusch and others) of recent years, or the production of the so-called "Third World," which had made its way to Europe during the last few years thanks in part to exposure in Berlin. The absence of really strong, human, authentic stories was bewildering. Instead, monsters glared from the screen, gallons of ketchup were spilled, sperm was sprayed -- all outside of space and time, in fictitious, albeit sometimes clever and skilfully contrived, stories. If a film did deal with reality, it treated pathological phenomena -- often not in order to reflect upon them, but in order to exploit their commercial potential, as in for example, the popular genre of the psycho-thriller. Why not, in the end? A film is also a product that must be sold. But it's a shame when commercial considerations invade areas where it would be more appropriate to support artistically more demanding projects.

\section{A post-modern love story}

This strange world doesn't seem to be made for pure love, and romantic desire always ends in bitter selfdeception. People are condemned to a loneliness that heightens their need for others and, at the same time, makes it impossible to fulfill that need. Director Wong Kar-wai expresses this feeling of existential loneliness in the form of a post-modern love story. Wong, labelled by Berlin critics as Hong Kong's Tarantino, had already displayed a brilliant talent in his Chungking Express (1994). At this year's Berlin festival, he presented his new film, Duoluo Tianshi (Fallen Angels, Hong Kong 1995), a variation on the themes of his older work. The dark and tragic fate of people lost in the anonymous cosmos of post-industrial civilization is portrayed in the fragmented lives of four people (the characters of a professional hit-man and his female boss predominate), whose paths intersect at random and then, at fateful moments, fail to cross.

The film's story, in which dialogue is entirely replaced by interior monologue, takes place at night, in darkened bars, empty underground passageways, and streets lit by garish advertisements. A mobile, freefloating camera roams through this labyrinthine megalopolis, deforming space and shapes in various ways, moving in and out of focus, speeding things up and slowing them down. The extreme intensity of these perceptions is supplemented by a montage of video clips, reinforcing the vision of chaos, disintegration, and alienation.

The excellent Spanish-American film Things I Never Told You (1995) presents another version of the postmodern love story. Director Isabel Coixet, in a spirit similar to that of Jarmusch's bitter comedies, portrays the troubles of a girl whose lover abandons her for work in Prague. The unfortunate Ann attempts to resolve the situation by means of videocassettes (she tapes messages for her ex-lover); after a suicide attempt, she finds consolation thanks to a psychiatrist from Hope Line, a telephone help line. A range of other characters appear in the film's episodic narrative structure -- characters who would also like to love somebody, but don't have anyone to love. The film finishes with an ironic happy ending.

British film is still alive

The British continue to save the reputation of the Old World. Although the opinion often prevails that 
British cinematography has long been merely a province of Hollywood, local production has maintained high standards along with its own originality and continuity. And British films were the most interesting set of films by a single nation at this year's festival in Berlin. Streetlife (1995) draws on the best British tradition of civilism, characterized by a documentary interest in everyday reality and a sensitivity to social problems. Its Welsh director, Karl Francis, originally made documentaries. With both realistic roughness and sympathy, he paints the portrait of an ordinary young woman who is full of life, sensitive, and selfsacrificing, despite her problems with work, money, and above all men. At the beginning of the film, the pregnant heroine happily plans her future with her partner; in the end, disappointed and abandoned, crushed by circumstances, she kills her newborn baby. Such authentic, humanely powerful films are few and far between. Jean Stewart's interesting debut, Nervous Energy (1995), convincingly portrays the changed relationship of, and the psychological changes undergone by, two homosexual lovers, one of whom has AIDS.

Another example of the British school was provided by Richard Loncraine's Machiavellian drama about bloody power intrigues -- his shocking present-day version of Shakespeare's Richard III. Transferring the action to the 1930s, he draws a direct parallel to the rise of the fascist dictators. The film contains shots that remind one of Leni Riefenstahl's monumental 1936 documentary Triumph of the Will. The walls of the royal palace are crushed by tanks, and everything ends in a frightening battle and destructive bombardment.

\section{The Presentation of the Bears}

Twenty-four films from eighteen countries all over the world were entered in the festival's competition. Although the Russian director Nikita Michalkov, president of the International jury, praised the consistent excellence of all the competing films when he announced the results and said that, in terms of the films' artistic quality, this year's Berlin festival was one of the best he had ever seen, the set of competing films was in fact the festival's greatest disappointment.

The romance Sense and Sensibility (director Ang Lee, USA 1995) won the Golden Bear for Best film. A Special prize of the Jury, the Silver Bear, was justly awarded to a classic of Swedish cinema, director Bo Widerberg, for his film Lust Och Fägring Stor (All Things Fair, Sweden/Denmark 1995). Set in 1943 against the background of the Second World War, the film portrays the erotic relationship of a fifteen-yearold schoolboy and his thirty-seven-year-old teacher. The tasteful, effectively narrated story of the young hero's coming of age, his first sexual experiences and disappointments, was notable for its human content, its traditional narration, and its purity of style. The Japanese film E No Naka No Boku No Mura (Village of Dreams, 1995) provided a similarly nostalgic look back: director Yoichi Higashi sensitively captures the childhood of two brothers and took away a Silver Bear for his "extraordinary creative achievement."

The jury awarded Silver Bears for Direction ex aequo to the Chinese director Yim Ho, whose film Tai Yang Yuo Er (The Sun Has Ears 1995) portrays a woman's gradual self-realization. After many injustices and despite her feelings, she rebels against the warlord who has virtually enslaved her and avenges his crimes. Her personal drama is intertwined with the political reality and social structure of the Chinese countryside in the 1920s. The other Silver Bear for direction went to Richard Loncraine for his Richard III.

Anouk Grinberg won the Silver Bear for Best actress for the main role in Mon Homme, the provocative work of the scandalous French director Bertrand Blier (1995). Walking the borderline between sentimental kitsch and whimsical parody, the film tells the story of a good-hearted prostitute with the symbolic name of Marie, who pursues her trade with gusto until the day she comes across a wretched homeless man, Jeannot, in a garbage heap. This pleasantly amoral, sexist, touching, romantic film is certain to call forth a polemical reaction. The American Sean Penn was named best actor for his performance as a criminal condemned to death in the psychological drama Dead Man Walking (director Tim Robbins, 1995).

The Tunisian film Halk-el-wad (A Summer In La Goulette, Tunis / France / Belgium 1996) constituted a pleasant surprise among the competing films; it failed, however, to win a prize. Director Ferid Boughedir (Halfaouine) fittingly called it "a comedy about tolerance"; with loving exaggeration he portrays the everyday life of an idiosyncratic seaside town, where Muslim, Jewish, and Christian families live together in peace. Regardless of faith and nationality, they share the same pleasures and cares: their modern-oriented maturing daughters try to lose their virginity; their fathers, fulfilling their traditional patriarchal role, try to stop them; and tolerant mothers, in accordance with tradition, maintain the household hearth. Claudia Cardinale was cleverly incorporated into this mosaic, playing herself as the famous CC on vacation in La Goulette. (She 
herself commented on her participation by noting that she has a personal interest in the town, for her mother was born there and she really does spend her vacations there.)

\section{Author Information}

Jiř́ VORÁČ is Chair of the Film Studies, at the Department of Theatre and Film Studies, Faculty of Arts, Masaryk University Brno, Czech Republic. His area of specialization includes Czech film history after 1945, interpretation and adaptation issues and film criticism. He wrote the book Czech and Slovak Film Directors in Exile (Palacký University, Olomouc, CR), and has contributed reviews to Film a doba, Iluminace and other publications. 